\title{
Screening and optimization of indole-3-acetic acid production by bacterial strain isolated from rice rhizosphere and its effects on plant growth
}

\author{
Biyas Mukherjee ${ }^{1,2}$, Sanchali Roy', Ankita Dhara', Sikha Dutta ${ }^{1 *}$ \\ ${ }^{1}$ Molecular Plant Pathology and Fungal Biotechnology Laboratory, Department of Botany, The \\ University of Burdwan, Purba Bardhaman 713104, West Bengal, India \\ ${ }^{2}$ Department of Botany, East Calcutta Girls' College, P 237, Lake Town Road, Block B, Sreebhumi, \\ Lake Town, Kolkata 700089, West Bengal, India \\ *Corresponding author, E-mail: sikha.bu.academia@gmail.com
}

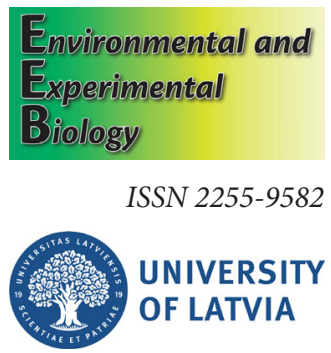

\begin{abstract}
The present study deals with the isolation of plant growth-promoting bacterial strains from rhizospheric soil collected from a rice field of Purba Bardhaman District, West Bengal, India. Among the isolated five strains, A5 was the best-performing strain as it had, plant growth promoting traits like, production of indole-3-acetic acid (IAA), siderophore, hydrogen cyanide and exopolysaccharides, ammonia, phosphate solubilization, nitrogen fixation etc. Strain A5, identified as Bacillus xiamensis by phenotypic characters and $16 \mathrm{~S}$ rDNA sequence-based homology, was able to produce a copious amount of IAA, particularly in the case of 42 -h culture with $1.5 \%$ L-tryptophan as a precursor. Media optimization with different carbon and nitrogen sources was conducted for maximum production of IAA. Strain A5 used fructose and casamino acid most efficiently as carbon and nitrogen sources, respectively. Growth parameters were increased in A5-treated seedlings of mung bean compared to control seedlings. Considering the observed traits, strain A5 can definitely be considered as a novel plant growth-promoting bacterial strain that may serve very well as a biofertilizer in agricultural fields.
\end{abstract}

Key words: Bacillus xiamensis, indole-3-acetic acid, plant growth-promoting rhizobacteria, plant growth promoting traits.

Abbreviations: ACC, 1-aminocyclopropane carboxylic acid;EPS, exopolysaccharide; IAA, indole-3-acetic acid; OD, optical density; PGPR, plant growth-promoting rhizobacteria

\section{Introduction}

The rhizosphere is the portion of soil surrounding the plant root and this region of soil is greatly influenced by plant root activity and metabolism (Prasad et al. 2019). A number of beneficial microbes inhabit the rhizosphere, among which bacteria are a dominant group. One gram of soil contains about $10^{8}$ to $10^{9}$ bacteria, $10^{5}$ to $10^{6}$ fungi, $10^{7}$ to $10^{8}$ actinomycetes, $10^{3}$ to $10^{6}$ algae, $10^{6}$ to $10^{8}$ archaea, $10^{3}$ to $10^{5}$ protozoa and 10 nematodes (Rughöft et al. 2016). Some groups of bacteria that have the capacity to utilize organic compounds released by plant roots (Jones 1990), and the plant forms a microenvironment where these few groups of bacteria can survive (Marilley et al. 1999; Barriuso et al. 2008). The groups of bacteria that are associated with plant roots have important roles in plant growth and productivity, and are collectively known as plant growth promoting rhizobacteria (PGPR) (Backer et al. 2018). PGPR are soil bacteria that colonize on the exterior and interior portion of the root (Backer et al. 2018). These bacteria belong to genera such as Microbacterium, Alcaligenes, Pantoea, Achromobacter, Rhizobium, Pseudomonas, Bacillus, Burkholderia, Erwinia, Azospirillum, Serratia etc. (Egamberdiyeva 2000; Tilak et al. 2005). PGPR have several traits by which they can accelerate plant growth via direct or indirect methods like phosphate solubilization, indole-3-acetic acid (IAA) production, atmospheric nitrogen fixation, ammonia production, $\mathrm{HCN}$ production, exopolysaccharide production etc. (Rodriguez et al. 1999).

IAA is the most active plant hormone of the auxin family and has important physiological roles in plants, such as embryo development, geotropism, phototropism, root initiation and root elongation etc. (Finet, Jaillais 2012). In addition, IAA contributes in root hair development and in the development of lateral branches of roots, facilitating nutrient uptake from the soil (Datta et al. 2000). Both plants and PGPR can synthesize physiologically active amounts of 
IAA via different inter-connected biosynthetic pathways, among which the tryptophan dependent pathway is well studied (Zhao 2010). Synthesis of the phytohormone IAA is one of the direct effects of PGPR on plant growth (Yousef 2018).

Our present work was focused on isolation, screening, characterization and identification of plant growthpromoting bacterial strains from a rice field of Purba Bardhaman District, with special reference to their IAA producing ability. The aim of our study was to isolate an IAA-producing PGPR strain and to increase IAA production by changing the concentration of L-tryptophan as well as carbon and nitrogen sources, to determine the optimum conditions at which maximum IAA production occurs. Plant growth promotion by isolated PGPR strains was checked on mung bean (Vigna radiata).

\section{Materials and methods}

\section{Isolation of bacteria from soil}

For isolation of rhizobacteria, rhizospheric soil samples were collected from a rice field of the agricultural farm of Golapbag Campus, Burdwan University $\left(23^{\circ} 14^{\prime} 20.86^{\prime \prime} \mathrm{N}\right.$, $\left.87^{\circ} 51^{\prime} 45.743^{\prime \prime} \mathrm{E}\right)$. For isolation, the dilution plate method was used, where about $0.5 \mathrm{~g}$ of soil was dissolved into 10 $\mathrm{mL}$ of double distilled water in a test tube and serially diluted up to 10 times. The plates were incubated at $28^{\circ} \mathrm{C}$ for $24 \mathrm{~h}$. After the incubation period, five colonies were obtained. The isolates were streaked on nutrient agar slants (peptone $5 \mathrm{~g}, \mathrm{NaCl} 5 \mathrm{~g}$, beef extract $1.5 \mathrm{~g}$, yeast extract $1.5 \mathrm{~g}$ and agar $15 \mathrm{~g}$, distilled water $1 \mathrm{~L}$ ). After $24 \mathrm{~h}$, when growth was sufficiently developed, they were preserved. After each 20 days the interval subculture procedure was continued.

Morphological characters like shape, surface, margin, colour, pigmentation, and odour of the selected bacterial strains were observed from 1-day-old colonies.

\section{Measurement of IAA}

Bacterial isolates were inoculated in liquid nutrient broth medium supplemented with $0.5 \%$ L-tryptophan and kept for $48 \mathrm{~h}$ on a rotary BOD shaker incubator at $27 \pm 2{ }^{\circ} \mathrm{C}$ temperature. After $48 \mathrm{~h}$ of growth, the bacterial cultures were centrifuged at $10000 \mathrm{rpm}$ for $10 \mathrm{~min}$ and $1 \mathrm{~mL}$ of supernatant was taken in a test tube mixed with $1 \mathrm{~mL}$ of Salkowski's reagent (35\% of perchloric acid, $1 \mathrm{~mL} 0.5$ $\mathrm{M} \mathrm{FeCl}_{3}$ ) solution. Then the reaction mixture was kept in dark condition for $20 \mathrm{~min}$. Appearance of a reddish-pink colour in the test tube indicated the production of IAA (Brick et al. 1991). Absorbance was taken at $530 \mathrm{~nm}$ and IAA concentration was estimated using a standard curve of auxin.

\section{Measurement of nitrogen fixation}

The five bacterial isolates were inoculated in Petri dishes containing Ashbay's mannitol agar media (devoid of any nitrogen source) for $48 \mathrm{~h}$ at $27 \pm 2{ }^{\circ} \mathrm{C}$ temperature in a BOD incubator. Occurrence of bacterial colonies indicated its ability to fix atmospheric nitrogen.

\section{Measurement of phosphate solubilization}

This test was done using the ammonium-molybdate method (Choi et al. 1996). Bacterial isolates were inoculated into Pikovskaya's broth medium and incubated at $27 \pm 2$ ${ }^{\circ} \mathrm{C}$ for $48 \mathrm{~h}$. After the incubation period, centrifugation was performed at $6000 \mathrm{rpm}$ for $10 \mathrm{~min}$. For preparation of solution A of Barton's reagent, ammonium molybdate (25 g) was dissolved in $400 \mathrm{~mL}$ distilled water. For preparation of solution $\mathrm{B}$, ammonium metavanadate $(1.25 \mathrm{~g})$ in 300 $\mathrm{mL}$ boil distilled water was dissolved and cooled, and then $250 \mathrm{~mL}$ concentrated $\mathrm{HNO}_{3}$ was added. Solution A and $B$ were mixed and the volume was made up to $1000 \mathrm{~mL}$ with distilled water. For analysis, $1 \mathrm{~mL}$ of culture filtrate was taken from each set and mixed with $2.5 \mathrm{~mL}$ Barton's reagent and the volume was made up to $5 \mathrm{~mL}$. The mixture was kept for $15 \mathrm{~min}$. Then optical density (OD) was taken at $430 \mathrm{~nm}$ wavelength and concentrations of solubilized phosphates were estimated with the standard $\mathrm{KH}_{2} \mathrm{PO}_{4}$ curve.

\section{Ammonia production ability}

Bacterial isolates were inoculated in peptone broth and incubated for $48 \mathrm{~h}$ at $27 \pm 2{ }^{\circ} \mathrm{C}$. After an incubation period, $1 \mathrm{~mL}$ of each culture was added to $0.5 \mathrm{~mL}$ of Nessler's reagent and development of yellowish orange colour indicated ammonia production by the bacterial isolates (Cappuccino, Sherman 1992).

\section{Hydrogen cyanide production ability}

Five isolated bacterial strains were streaked onto glycine supplemented nutrient agar plates. Whatman filter paper No. 1 was dipped in $2 \%$ sodium carbonate (dissolved in $0.5 \%$ picric acid solution), which was impregnated at the inner surface of the lid of the Petri dishes. The dishes were carefully covered with parafilm and incubated at $27 \pm 2$ ${ }^{\circ} \mathrm{C}$ for $72 \mathrm{~h}$. Development of an orange to brown color on the filter paper indicated that the bacterial strain had the capability to produce hydrogen cyanide (Lorck 1948).

\section{Measurement of siderophore production}

The siderophore activity of selected isolates was determined following the Chrome Azural S agar plate method (Schwyn, Neilands 1987). To prepare $1 \mathrm{~L}$ of blue agar, solution I was prepared by dissolving $6.05 \mathrm{mg}$ Chrome Azural S in $5 \mathrm{~mL}$ of distilled water and mixed with $1 \mathrm{~mL}$ of $1 \mathrm{mM} \mathrm{FeCl} 3$ in $10 \mathrm{mM} \mathrm{HCl}$ with stirring. This solution was slowly added to $7.29 \mathrm{mg}$ hexadecyltrimethylammonium bromide dissolved in $4 \mathrm{~mL}$ water. Solution II contained $90 \mathrm{~mL}$ CAAB media ( $5 \mathrm{~g} \mathrm{~L}^{-1}$ casamino acid, $1.18 \mathrm{~g} \mathrm{~L}^{-1} \mathrm{~K}_{2} \mathrm{HPO}_{4}, 0.25 \mathrm{~g} \mathrm{~L}^{-1} \mathrm{MgSO}_{4}$ $7 \mathrm{H}_{2} \mathrm{O}, \mathrm{pH}$ 5.6) and $2 \mathrm{~g}$ agar was added after adjustment of the $\mathrm{pH}$ of medium. PIPES buffer powder $(3.024 \mathrm{~g})$ was 
added to $90 \mathrm{~mL}$ of media. Solutions I and II were autoclaved separately. After that, both solutions were cooled to 50 ${ }^{\circ} \mathrm{C}$ and solution I was added along the glass wall of an Erlenmeyer's flask with enough agitation to achieve mixing without generation of foam. Then, the prepared blueCAS agar media was poured in Petri dishes, maintaining a volume of $25 \mathrm{~mL}$. Bacterial isolates were streaked into the plates and incubated at $27 \pm 2{ }^{\circ} \mathrm{C}$ for $72 \mathrm{~h}$. An orange coloured zone around a colony indicated a positive result.

\section{Measurement of exopolysaccharides}

Bacterial strains were grown in nutrient broth in a BOD incubator for $48 \mathrm{~h}$ at $27 \pm 2{ }^{\circ} \mathrm{C}$. After an incubation period, the cultures were centrifuged at $7000 \mathrm{rpm}$ for $10 \mathrm{~min}$. Supernatant $(1 \mathrm{~mL})$ was mixed with $3 \mathrm{~mL}$ of acetone and re-centrifuged, and this process was repeated 5 times. Then the pellet was suspended with distilled water. An aliquot of $1 \mathrm{~mL}$ of this solution was added to $1 \mathrm{~mL}$ of $5 \%$ aqueous phenol and $5 \mathrm{~mL}$ of concentrated $\mathrm{H}_{2} \mathrm{SO}_{4}$ and kept for 20 min. Presence of a brownish-red colour indicated the ability of production of exopolysaccharides by the bacterial strain. The OD value was measured at $490 \mathrm{~nm}$ wavelength and concentration was determined using a standard glucose curve (Dubois et al. 1956).

\section{Utilization of ACC as a sole nitrogen source}

The ability of bacterial isolates to use 1-aminocyclopropane1-carboxylic acid (ACC) as a nitrogen source was tested by growing the bacteria in Davis Mingoli's media plates (without a nitrogen source) supplemented with $0.5 \mathrm{M}$ ACC. It was then kept it in an incubator at $27 \pm 2{ }^{\circ} \mathrm{C}$ temperature for $48 \mathrm{~h}$. Appearance of bacterial colonies in the plates indicated the ability of that particular bacteria to use ACC as a nitrogen source (Sarkar et al. 2017).

\section{IAA production ability of $A 5$}

Cell density of A5 was measured at 6-h interval by taking the $\mathrm{OD}$ value at $540 \mathrm{~nm}$ and the amount of IAA production was determined using the method mentioned above (Brick et al. 1991). PGPR strain A5 was inoculated in nutrient broth containing different concentration of L-tryptophan $(0.5,1,1.5$, and $2 \%)$ to serve as the precursor of IAA and incubated for $42 \mathrm{~h}$ at $27 \pm 2{ }^{\circ} \mathrm{C}$ temperature. Then, the concentration of IAA in all sets was measured (Brick et al. 1991).

The amount of IAA production by the selected strain A5 was checked in Davis Mingoli's media supplemented with different nitrogen source like ammonium chloride, ammonium sulphate, glycine, leucine, asparagines and casamino acid. After $42 \mathrm{~h}$ of growth, all media containing cultures were centrifuged at $6000 \mathrm{rpm}$ for $12 \mathrm{~min}$. The supernatant was mixed with an equal volume of Salkawsky's reagent. After $15 \mathrm{~min}$, OD was taken at $530 \mathrm{~nm}$ wavelength (Brick et al. 1991). For optimization of the carbon source, Davis Mingoli's media plates supplemented with different carbon sources (glucose, maltose, sucrose, mannitol and fructose) were prepared. After $42 \mathrm{~h}$ of growth, all five culture sets were centrifuged at $6000 \mathrm{rpm}$ for $12 \mathrm{~min}$. The supernatant was mixed with an equal volume of Salkowsky's reagent. After $15 \mathrm{~min}$, a pink colour appeared and OD was taken at $530 \mathrm{~nm}$ wavelength (Brick et al. 1991).

\section{Identification of the selected bacterial strain A5}

The selected bacterial strain was identified by morphological characters as well as by using the $16 \mathrm{~S}$ rDNA sequencing method. Standard phenol/chloroform extraction (Sambrook et al. 1989) was used to isolate genomic DNA, followed by PCR amplification of the 16S rRNA gene using universal primers 16F27 [5'-CCA GAG TTT GAT CMT GGC TCA G-3'] and 16R1492 [5'-TAC GGY TAC CTT GTT ACG ACT T-3']. The amplified 16S rRNA gene PCR product was purified by PEG- $\mathrm{NaCl}$ precipitation and directly sequenced on an $\mathrm{ABI}^{\circ} 3730 \mathrm{XL}$ automated DNA sequencer. Sequencing was carried out from both ends using additional internal primers so that each position was read at least twice. Assembly was carried out using the Laser gene package followed by identification using the NCBI database. Jukes and Cantor's method was used for constructing a phylogenetic tree with MEGA X software.

\section{Plant growth test on mung bean using A5 strain}

Mature mung bean (Vigna radiata L. Wilczek.) seeds were surface sterilized with $0.1 \% \mathrm{NaOCl}$ for 2 min followed by washing with sterile distilled water and then the water was decanted. The seeds were then kept on sterilized moist blotting paper and incubated in dark at $24 \pm 2{ }^{\circ} \mathrm{C}$ temperature for 3 days and then transferred in a growth room (RH 70 to $80 \%$, temperature $30 \pm 2{ }^{\circ} \mathrm{C}$, illumination $270 \mu \mathrm{E} \mathrm{m}^{-2} \mathrm{~s}^{-1}$, photoperiod $12 \mathrm{~h}$ ). A $2 \mathrm{~mL}$ sample of bacterial culture (A5) at a cell density of $1 \times 10^{8} \mathrm{CFU} \mathrm{mL} \mathrm{mL}^{-1}$ was added in one set of petri dishes (inoculated set). Seeds treated with sterilized water instead of bacterial culture were considered as a control. No fertilizer was applied for seedling growth in any of the sets.

Several plant growth parameters like germination percentage root and shoot length, dry weigh of root and shoot, amount of chlorophyll were measured for 20 days seedling in both sets. All experiments were performed in triplicate and the numbers of seedlings were three per replicate.

Germination percentage (GP) was calculated following this formula:

$\mathrm{GP}=$ total number of seeds germinated / total number of seeds) $\times 100$.

For extraction of chlorophyll, $3 \mathrm{~g}$ of fresh leaf tissue was taken from each set and ground with $80 \%$ acetone and then centrifuged at $10000 \mathrm{rpm}$ for $6 \mathrm{~min}$; this process was repeated three to four times until the precipitate become colourless. Then the supernatant was taken and absorbance was recorded against acetone at $645 \mathrm{~nm}$ and 
$663 \mathrm{~nm}$ (Arnon 1949). The concentration of chlorophyll $a$, chlorophyll $b$ and total chlorophyll was calculated by this formula:

Total chlorophyll $\left(\mathrm{mg} \mathrm{g}^{-1} \mathrm{FW}\right)=\left(20.2 \mathrm{~A}_{645}+8.02 \mathrm{~A}_{663}\right) \times$ total volume of filtrate / $1000 \times$ tissue weight;

Chlorophyll $a\left(\mathrm{mg} \mathrm{g}^{-1} \mathrm{FW}\right)=\left(12.7 \mathrm{~A}_{663}-2.69 \mathrm{~A}_{645}\right) \times$ total volume of filtrate / $1000 \times$ tissue weight;

Chlorophyll $b\left(\mathrm{mg} \mathrm{g}^{-1} \mathrm{FW}\right)=\left(22.9 \mathrm{~A}_{645}-4.68 \mathrm{~A}_{663}\right) \times$ total volume of filtrate / $1000 \times$ tissue weight.

\section{Results}

\section{Isolation, screening and characterization of PGPR}

Five bacterial colonies with distinct morphology were isolated. Morphological features of the five isolates were analyzed (Table 1). Different plant growth-promoting traits like IAA production, nitrogen fixation, phosphate solubilisation, ammonia production, $\mathrm{HCN}$ production and exopolysaccharide production were assessed for the five isolated bacterial strains (Table 2). Strain A5 was found to produce a large amount of IAA using L-tryptophan as a precursor followed by the strain A4 (Fig. 1). A5 was found to solubilize highest amount of tricalcium phosphate among the five isolates, although all five isolates had phosphate solubilizing capacity (Fig. 2). Strain A5 produced the highest amount of exopolysaccharide among the five strains (Fig. 3). A5 was selected as the best-performing PGPR strain as it displayed all other plant growth-promoting traits thus far tested (Table 2).

\section{Factors influencing IAA production by $A 5$ strain}

Growth of A5 was highest at $42 \mathrm{~h}$ and IAA production also reached a peak at that time (Fig. 4). IAA production of A5 was highest when the plate was supplemented with
1.5\% L-tryptophan (Fig. 5). To optimize the nitrogen source of the media for maximum production of IAA, different nitrogen sources were used (ammonium chloride, ammonium sulphate, glycine, leucine, asparagine and casamino acid). A5 produced highest amount of IAA when casamino acid was supplied as the nitrogen source (Fig. 6). For the selection of the best carbon source to obtain the highest amount of IAA, different sugars (glucose, maltose, sucrose, mannitol, and fructose) were used in Davis Mingoli's broth media. A5 most efficiently used keto sugar fructose as the carbon source (Fig. 7).

\section{Identification of A5 strain}

Morphological characterization showed that A5 was a gram positive bacteria with the following features: long thin rods, colony size 5 to $10 \mathrm{~nm}$, colour white, shape round, margin entire, opacity opaque, consistency smooth, and elevation flat. The total length of the $16 \mathrm{~S}$ rDNA sequence of the A5 strain was 1200 nucleotide bp. The 1200 bp nucleotide sequences were compared to data in the nucleotide bank, which showed that the closest neighbour of the strain A5 was Bacillus xiamenensis HYC-10(T) (AMSH01000114) with $99.92 \%$ similarity. A phylogenetic tree was generated using MEGA X software with Jukes and Cantor's correction (1969) (Fig. 8). Phylogenetic analyses conducted using $16 \mathrm{~S}$ rDNA sequences from type strains of all Bacillus spp. with greater than $98 \%$ similarity proved its position within the genus Bacillus. In the phylogenetic tree, A5 formed a clade within the cluster represented by Bacillus xiamenensis (AMSH01000114) and Bacillus xiamenensis (NR_148244). A5 strain showed closest similarity with Bacillus xiamenensis (AMSH01000114) (99.92\%); followed by Bacillus xiamenensis (NR_148244) (99.25\%) and Bacillus stratophericus (NR_118441) (99.17\%).

Table 1. Morphological characteristics of the five isolated strains

$\begin{array}{lllllll}\text { Isolate } & \text { Shape } & \text { Surface } & \text { Margin } & \text { Colour } & \text { Pigmentation } & \text { Odour } \\ \text { A1 } & \text { Round } & \text { Smooth-shiny } & \text { Smooth } & \text { Whitish } & \text { None } & \text { Odorless } \\ \text { A2 } & \text { Round } & \text { Smooth-shiny } & \text { Smooth } & \text { Pinkish white } & \text { None } & \text { Odorless } \\ \text { A3 } & \text { Indistinct } & \text { Smooth-shiny } & \text { Wavy } & \text { Creamy-white } & \text { None } & \text { Odorless } \\ \text { A4 } & \text { Round } & \text { Smooth-shiny } & \text { Smooth } & \text { Whitish } & \text { None } & \text { Odorless } \\ \text { A5 } & \text { Round } & \text { Smooth-shiny } & \text { Smooth } & \text { Whitish } & \text { None } & \text { Odorless }\end{array}$

Table 2. Characterization of plant growth promoting traits (nitrogen fixation, siderophore production, ammonia production, HCN production, ability to use 1-aminocyclopropane-1-carboxylic acid (ACC) as nitrogen source) of the five isolated strains. P, present; N, not present

\begin{tabular}{llllll} 
Isolate & Nitrogen fixation & $\begin{array}{l}\text { Siderophore } \\
\text { production }\end{array}$ & $\begin{array}{l}\text { Ammonia } \\
\text { production }\end{array}$ & HCN production & $\begin{array}{l}\text { DM media without } \\
\text { ammonium sulphate + ACC }\end{array}$ \\
A1 & $\mathrm{N}$ & $\mathrm{P}$ & $\mathrm{N}$ & $\mathrm{N}$ \\
$\mathrm{A} 2$ & $\mathrm{~N}$ & $\mathrm{~N}$ & $\mathrm{P}$ & $\mathrm{N}$ & $\mathrm{N}$ \\
$\mathrm{A} 3$ & $\mathrm{P}$ & $\mathrm{N}$ & $\mathrm{N}$ & $\mathrm{N}$ & $\mathrm{N}$ \\
$\mathrm{A} 4$ & $\mathrm{~N}$ & $\mathrm{~N}$ & $\mathrm{P}$ & $\mathrm{N}$ & $\mathrm{N}$ \\
$\mathrm{A} 5$ & $\mathrm{P}$ & $\mathrm{P}$ & $\mathrm{P}$ & $\mathrm{P}$ & $\mathrm{P}$ \\
\hline
\end{tabular}




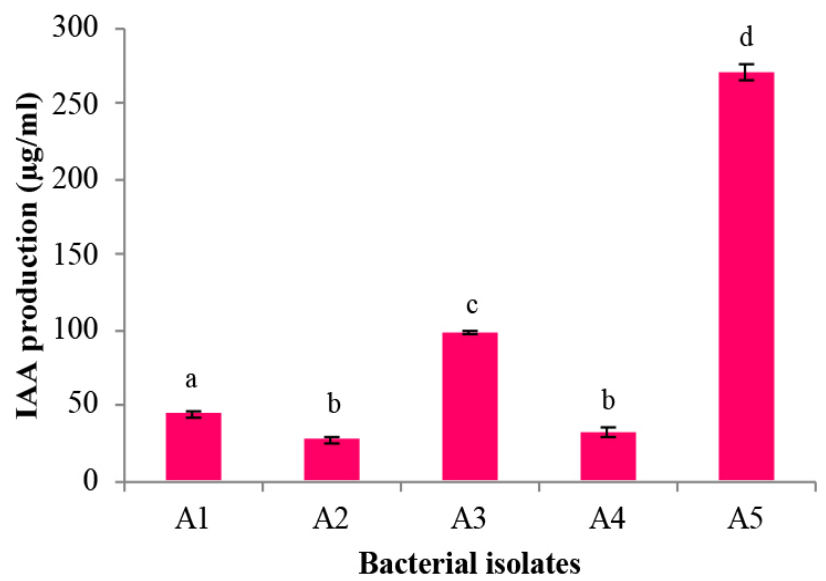

Fig. 1. Concentration of indole-3-acetic acid (IAA) produced by five bacterial isolates among which A5 showed highest IAA production. Different letters indicate statistically significant differences between groups (mean $\pm \mathrm{SD}, n=3, p<0.05$ ).

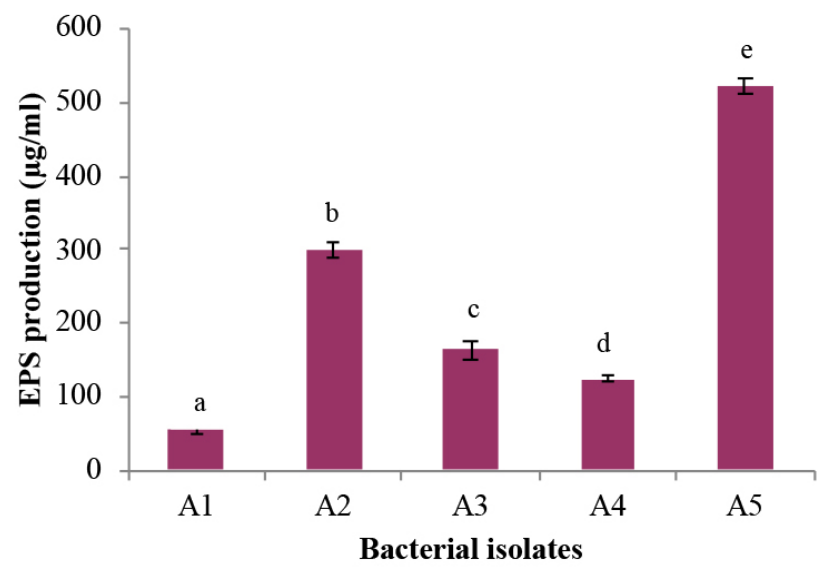

Fig. 3. Concentration of exopoysachharides (EPS) $\left(\mu \mathrm{g} \mathrm{mL}^{-1}\right)$ produced by five bacterial isolates. Different letters indicate statistically significant differences between groups (mean $\pm \mathrm{SD}$, $n=3, p<0.05)$.

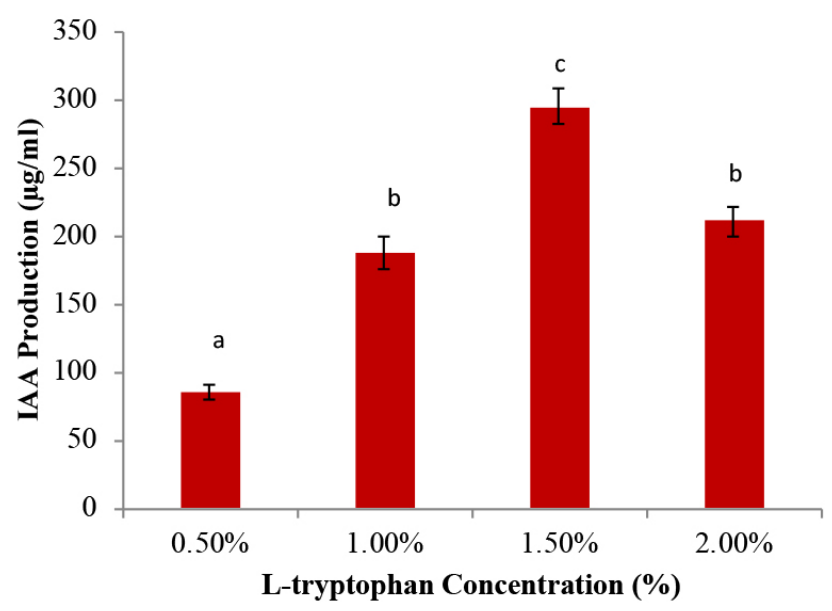

Fig. 5. Effect of different concentrations of L-tryptophan on amount of indole-3-acetic acid (IAA) $\left(\mu \mathrm{g} \mathrm{mL}^{-1}\right)$ produced by the strain A5. Different letters indicate statistically significant differences between groups (mean $\pm \mathrm{SD}, n=3, p<0.05$ ).

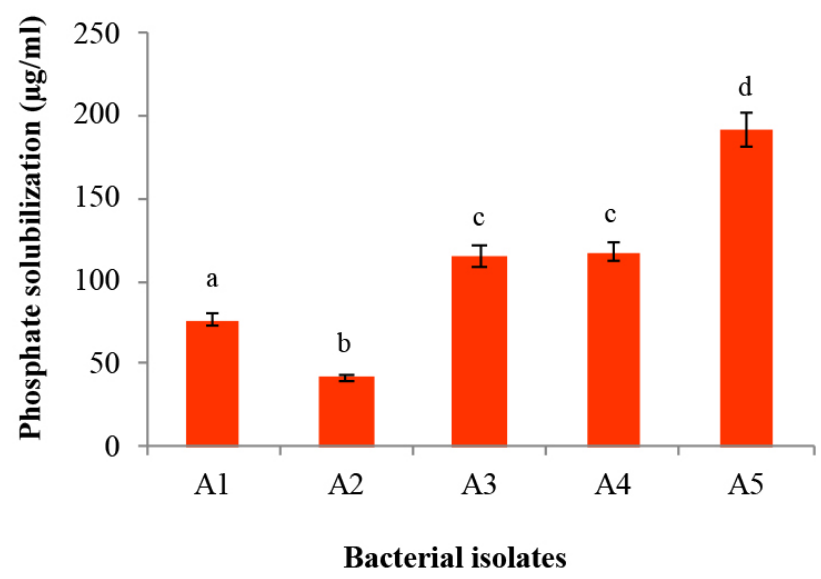

Fig. 2. Concentration of insoluble phosphate $\left(\mu \mathrm{g} \mathrm{mL}^{-1}\right)$ (tricalcium phosphate) solubilized by five bacterial isolates. Different letters indicate statistically significant differences between groups (mean $\pm \mathrm{SD}, n=3, p<0.05$ ).

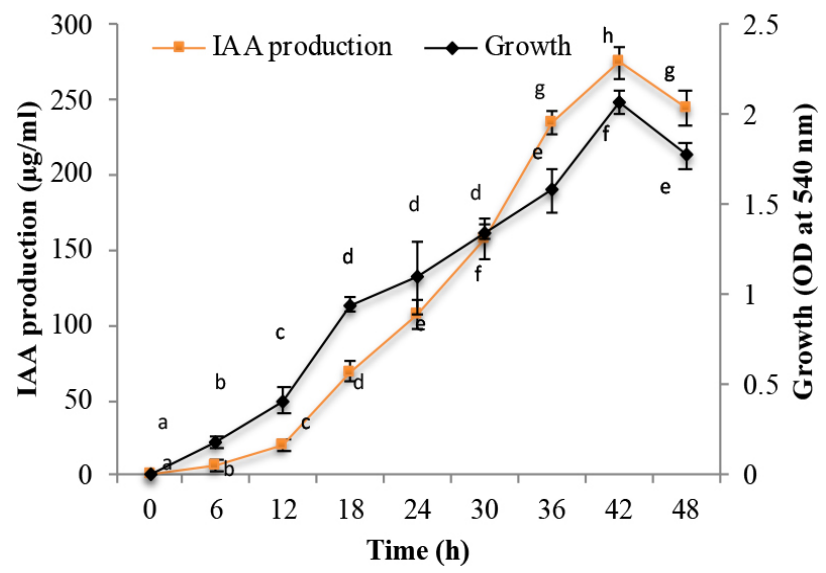

Fig. 4. Growth curve of selected A5 strain and indole-3-acetic acid (IAA) production $\left(\mu \mathrm{gL}^{-1}\right)$ by the bacteria up to $48 \mathrm{~h}$ in six hours interval. Different letters indicate statistically significant differences between groups (mean $\pm \mathrm{SD}, n=3, p<0.05$ ).

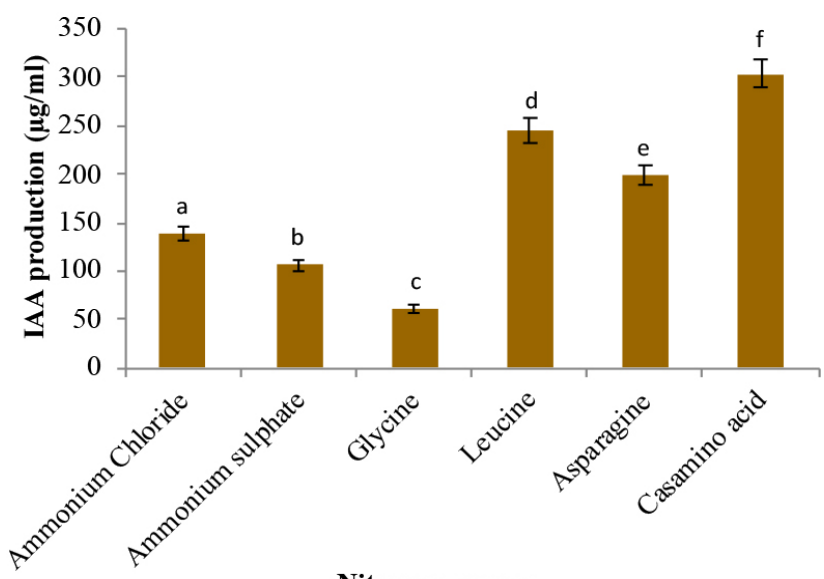

Nitrogen source

Fig. 6. Effect of different nitrogen sources on concentration of indole-3-acetic acid (IAA) $\left(\mu \mathrm{g} \mathrm{mL}^{-1}\right)$ produced by the strain A5. Different letters indicate statistically significant differences between groups (mean $\pm \mathrm{SD}, n=3, p<0.05$ ). 


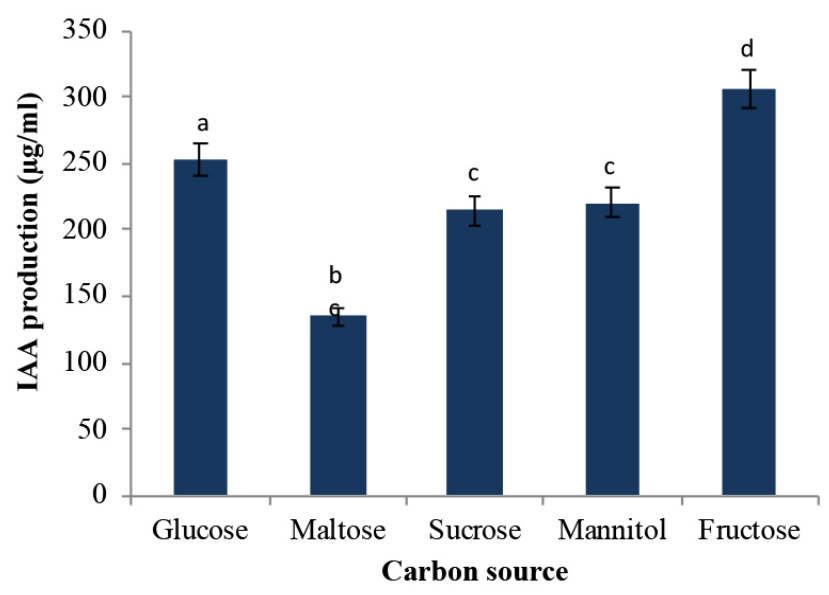

Fig. 7. Effect of different carbon sources on amount of indole-3acetic acid (IAA) $\left(\mu \mathrm{g} \mathrm{m}^{\mathrm{L}-1}\right)$ produced by the strain A5. Different letters indicate statistically significant differences between groups (mean $\pm \mathrm{SD}, n=3, p<0.05$ ).

\section{Response of mung bean seedlings to inoculation with A5 strain}

The inoculation of A5 on mung bean seedlings showed satisfactory promotion in terms of plant growth compared to non-inoculated sets. The germination percentage, morphological parameter of roots (root dry weight, root length), shoot morphological parameters (shoot dry weight, shoot length) and chlorophyll concentration were higher in A5-inoculated seedlings compared to the control set (Table 3).

\section{Discussion}

Plant growth-promoting soil bacteria that fit into compatible niches without causing any disease are selected by the plant (Etesami 2015). After microbial recognition, PGPRs have to overcome the plant defense system to survive in the rhizosphere (Soto et al. 2006). IAA produced by PGPR is thought to have some role in combating the plant defense responses (Spaepen et al. 2007). IAA has no function in bacterial cells but it may help to establish the plant-microbial interaction (Patten, Glick 2002). Producion of IAA by PGPR increases the amount of root exudates by loosening the plant cell wall, which facilitates bacterial colonization (James et al. 2002; Chi et al. 2005). It also increases root length and surface area, which leads to a greater amount of nutrient and water uptake (Vessey 2003). Thus, in vitro capacity of IAA production can be regarded as a dependable source for selection of the best-performing PGPR in screening.

In this study, among the five isolated bacterial strains, A5 was selected as the best-performing PGPR on the basis of in vitro IAA production ability and other plant growthpromoting traits. IAA production as well as growth of A5 was highest at $42 \mathrm{~h}$ of culture and then both started to decline. Addition of L-tryptophan in the culture media enhanced the amount of IAA production, as it is a precursor of IAA (Ahmed et al. 2005; Santi et al. 2007; Sridevi et al. 2007). Here also, it was found that the amount of IAA production increased simultaneously with increasing concentration of L-tryptophan up to $1.5 \%$. Our results are similar with previous studies showing the enhancement of L-tryptophan dependent IAA synthesis several fold (Khalid et a. 2004; Bharucha et al. 2013).

IAA production by PGPR varies with different carbon sources (Wang et al. 1987; Santi et al. 2007; Sridevi et al. 2008). The carbon source has a huge contribution to the overall efficiency of IAA biosynthesis. In this study, five different sugars (glucose, mannitol, fructose, maltose, sucrose) were used to evaluate their effect on IAA production, from which fructose was utilized most efficiently by A5 for IAA production. Monosaccharides were better carbon sources than disaccharides. Mannitol and L-glutamic acid were the most suitable sources for IAA

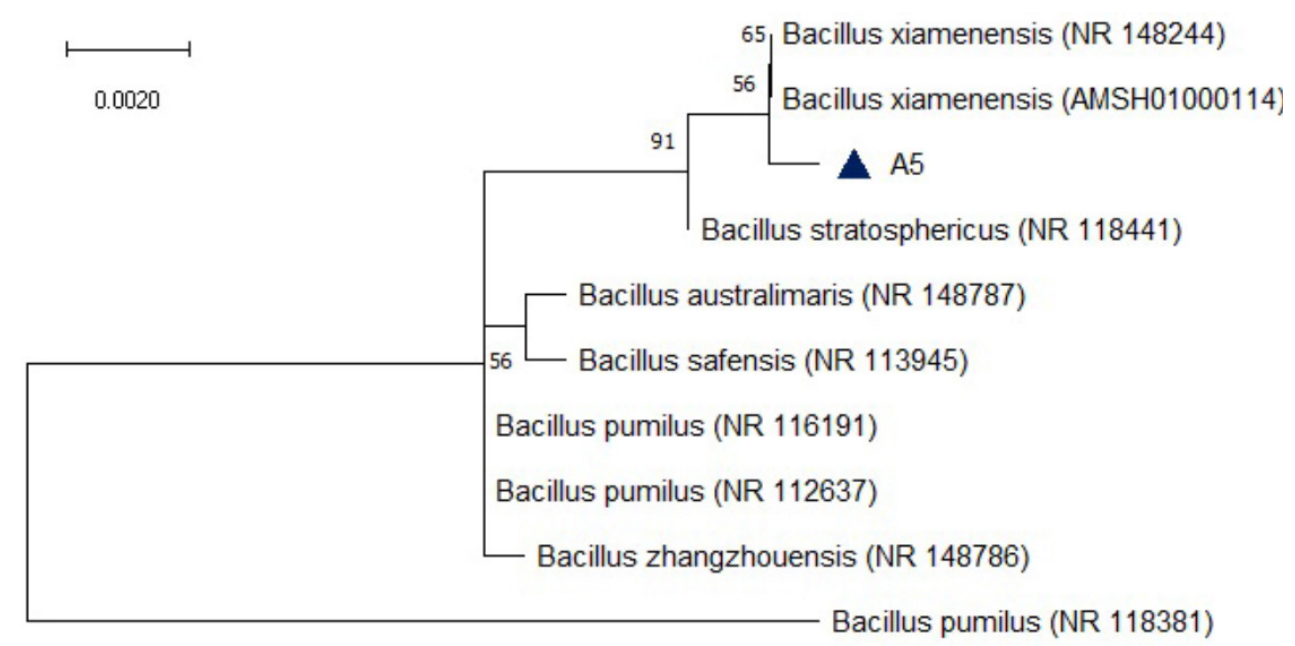

Fig. 8. The tree generated using MEGA X software with Jukes and Cantor's correction (1969). Bootstrap values of 1000 replications expressed as percentages are given at branch points. 
Table 3. Different growth parameters were tested in both un-inoculated as well as A5-treated seedlings of mung bean (Vigna radiata). Different letters indicate statistically significant differences between groups. Data presented here are the mean of three replicates; mean $\pm \mathrm{SD}$, one way ANOVA, $\mathrm{p}<0.05)$

$\begin{array}{lccc}\text { Growth parameter } & \text { Uninoculated set } & \text { Inoculated set } & \text { Relative change (\%) } \\ \text { Germination }(\%) & 92.3 \pm 3.51 \mathrm{a} & 99.6 \pm 0.57 \mathrm{~b} & 7.87 \pm 2.0 \\ \text { Root length }(\mathrm{cm}) & 4.74 \pm 0.05 \mathrm{a} & 6.2 \pm 0.04 \mathrm{a} & 28.94 \pm 6.1 \\ \text { Shoot length }(\mathrm{cm}) & 9.24 \pm 0.12 \mathrm{a} & 9.88 \pm 0.11 \mathrm{a} & 6.7 \pm 0.97 \\ \text { Root dry weight }(\mathrm{mg}) & 5.36 \pm 0.065 \mathrm{a} & 5.49 \pm 0.015 \mathrm{a} & 3.41 \pm 2.5 \\ \text { Shoot dry weight }(\mathrm{mg}) & 8.25 \pm 0.05 \mathrm{a} & 8.68 \pm 0.060 \mathrm{a} & 5.0 \pm 1.18 \\ \text { Concentration of chlorophyll } a\left(\mathrm{mg} \mathrm{g}^{-1}\right) & 2.64 \pm 4.31 \mathrm{a} & 5.94 \pm 2.11 \mathrm{~b} & 146.6 \pm 74.03 \\ \text { Concentration of chlorophyll } b\left(\mathrm{mg} \mathrm{g}^{-1}\right) & 1.41 \pm 2.44 \mathrm{a} & 4.56 \pm 3.04 \mathrm{~b} & 226.4 \pm 32.43 \\ \text { Total concentration of chlorophyll }\left(\mathrm{mg} \mathrm{g}^{-1}\right) & 4.35 \pm 4.62 \mathrm{a} & 10.38 \pm 3.33 \mathrm{~b} & 144.91 \pm 37.82\end{array}$

production by Rhizobium (Sridevi et al. 2008). Sucrose was the preferred carbon source by Pseudomonus putida for IAA production (Bharucha et al. 2013). Soil bacteria isolated from Stevia rebaudiana rhizosphere most efficiently used dextrose as a carbon source to produce IAA (Chandra et al. 2018).

The nitrogen source present in the culture media affects IAA production of bacteria (Santi et al. 2007; Sridevi et al. 2008; Leelahawonge, Pongsilp 2009). In this study, six different nitrogen sources (ammonium chloride, ammonium sulphate, glycine, leucine, asparagines and casamino acid) were tested for their effect on IAA production, from which casamino acid was utilized most efficiently by A5 for IAA production. Pseudomonus putida utilized ammonium sulphate most suitably as a nitrogen source for production of IAA (Bharucha et al. 2013). To produce IAA, ammonium chloride was preferably used by Pseudomonus fluorescence as nitrogen source (Jeyanthi, Ganesh 2013). Another study showed that Pseudomonus sp. used yeast extract as the best nitrogen source (Balaji et al. 2012).

A5 was not only a nitrogen fixer but also it has the capacity to produce ammonia from nitrogen containing peptone. A5 can solubilize an insoluble form of phosphate, which is in agreement with other studies on PGPR (Mukherjee et al. 2019). The strain A5 produced good amount of siderophores that chelate iron, resulting in grester uptake of Fe (Maheswari 2012). PGPR secretes several metabolites that trigger plant growth and prevent pathogen infection and produce exo-polysaccharides, which prevent the movement of toxic ions and adjust the ionic balance and water transport in plant tissues, while controlling the pathogenic microbial population (Ramalingam et al. 2017). Here, A5 produced a suitable amount of $\mathrm{HCN}$-a secondary metabolite, which aids in plant defense (Abd El-Rahman et al. 2019) and exopolysaccharide produced by A5 may help to withstand stress (Nadeem et al. 2010; Upadhyay et al. 2011; Kim et al. 2014; Habib et al. 2016).

The selected best-performing A5 strain was identified as Bacillus xiamenensis based on phenotypic features and $16 \mathrm{~S}$ rDNA sequence-based homology. An identical strain with plant growth-promoting activity has also been reported earlier (Amna et al. 2020).

The application of the A5 strain on mung bean showed enhancement of germination, root and shoot length, root dry weight and chlorophyll concentration. There may be a correlation between plant growth promoting traits of A5 and the increased seedling growth. A5 produces large amount of IAA, which promotes germination and root growth (Kim et al. 2014). A significant increase in shoot and root biomass and chlorophyll concentration was found in Solanum lycopersicum treated with an IAA-producing isolate compared to control plants (Khan et al. 2016). PGPR have the ability to the increase plant growth considerably (Karnwal 2017).

Considering the above results, it may be concluded that, IAA-producing PGPRs enhance plant growth and optimization of the parameters that influence IAA production will further promote growth. This technology could be used to minimize the environmental pollution in crop fields produced by excessive use of chemical fertilizers.

\section{Acknowledgements}

The authors are very much thankful to infrastructure and instruments provided by Molecular Plant Pathology and Fungal Biotechnology Laboratory, UGC-CAS Department of Botany, the University of Burdwan.

\section{References}

Abd El-Rahman A.F., Shaheen A.H., Abd El-Aziz R.M., Ibrahim D.S.S. 2019. Influence of hydrogen cyanide-producing rhizobacteria in controlling the crown gall and root-knot nematode, Meloidogyne incognita. Egypt. J. Biol. Pest Contr. 29: 41.

Ahmad F., Ahmad I., Khan M.S. 2005. Indole acetic acid production by the indigenous isolates of Azotobacter and fluorescent Pseudomonas in the presence and absence of tryptophan. Turkish J. Biol. 29: 29-34.

Amna, Xia Y., Farooq M.A., Javed M.T., Kamran M.A., Mukhtar T., Ali J., Tabassum T., Rehman S., Munis M.F.H., Sultan T., Chaudhary H.J. 2020. Multi-stress tolerant PGPR Bacillus xiamenensis PM14 activating sugarcane (Saccharum 
officinarum L.) red rot disease resistance. Plant Physiol. Biochem. 151: 640-649.

Arnon D. 1949. Copper enzymes in isolated chloroplasts. Polyphenol oxidase in Beta vulgaris. Plant Physiol. 24: 1-15.

Backer R., Rokem J.S., Ilangumaran G., Lamont J., Praslickova D., Ricci E., Subramanian S., Smith D.L. 2018. Plant growth promoting rhizobacteria: context, machanisms of action, and roadmap to commercialization of biostimulants for sustainable agriculture. Front. Plant Sci. 9: 1473.

Balaji N., Lavanya S.S., Muthamizhselvi S., Tamilarasan K. 2012. Optimization of fermentation condition for indole acetic acid production by Pseudomonas species. Int. J. Adv. Biotechnol. Res. 3: 797-803.

Barriuso J., Solano B.R., Lucas J.A., Lobo A.P., García-Villaraco A., Mañero F.J.G. 2008. Ecology, genetic diversity and screening strategies of plant growth promoting rhizobacteria (PGPR). In: Ahmad I., Pichtel J., Hayat S. (Eds.) PlantBacteria Interactions. Strategies and Techniques to Promote Plant Growth. Wiley, Weinheim, pp. 1-17.

Bharucha U., Patel K., Trivedi U.B. 2013. Optimization of indole acetic acid production by Pseudomonas putida UB1 and its effect as plant growth-promoting rhizobacteria on mustard (Brassica nigra). Agric. Res. 2: 215-221.

Brick J.M., Bostock R.M., Silverstone S.E. 1991. Rapid in situ assay for indole acetic acid production by bacteria immobilized on nitrocellulose membrane. Appl. Environ. Microbiol. 57: 535538.

Cappuccino J.C., Sherman N. 1992. Microbiology. A Laboratory Manual. $3^{\text {rd }}$ Ed. Benjamin Cummings Publishers, New York.

Chandra S., Askari K., Kumari M. 2018. Optimization of indole acetic acid production by isolated bacteria from Stevia rebaudiana rhizosphere and its effects on plant growth. J. Genet. Eng. Biotechnol. 16: 581-586.

Chi F., Shen S.H., Cheng H.P., Jing Y.X., Yanni Y.G., Dazzo F.B. 2005. Ascending migration of endophytic rhizobia, from roots to leaves inside rice plants and assessment of benefits to rice growth physiology. Appl. Environ. Microbiol. 71: 7271-7278.

Datta C., Basu P.S. 2000. Indole acetic acid production by a Rhizobium species from root nodules of a leguminous shrub, Cajanus cajan. Microbiol. Res. 155: 123-127.

Dubois M., Gilles K.A., Hamilton J.K., Rebers R.A., Smith F. 1956. Colorimetric method for determination of sugar and related substances. Anal. Chem. 28: 350-356.

Egamberdiyeva D. 2000. Plant-growth-promoting rhizobacteria isolated from a Calcisol in a semi-arid region of Uzbekistan: biochemical characterization and effectiveness. J. Plant Nutr. Soil Sci. 168: 94-99.

Etesami H., Alikhani H.A., Hosseini H.M. 2015. Indole-3-acetic acid (IAA) production trait, a useful screening to select endophytic and rhizosphere competent bacteria for rice growth promoting agents. MethodsX 63: 72-78.

Finet C., Jaillais Y. 2012. Auxology: when auxin meets plant evodevo. Dev. Biol. 369: 19-31.

Lorck H. 1948. Production of hydrocyanic acid by bacteria. Plant Physiol. 1: 142-146.

Habib S.H., Kaussar H., Saud H.M. 2016. Plant growth-promoting rhizobacteria enhance salinity stress tolerance in okra through ROS-scavenging enzymes. BioMed Res. Int. 2016: 6284547.

James E.K., Gyaneshwar P., Mathan N., Barraquio W.L., Reddy P.M., Iannetta P.P.M., Olivars F.L., Ladha J.K. 2002. Infection and colonization of rice seedlings by the plant growthpromoting bacterium Herbaspirillum seropedicae Z 67. Mol.
Plant Microbe Interact. 15: 894-906.

Jeyanthi V., Ganesh P. 2013. Production, optimization and characterization of phytohormone indole acetic acid by Pseudomonas fluorescence. Int. J. Pharm. Biol. Arch. 4: 514-520.

Jones D. 1990. The Rhizosphere. John Wiley \& Sons, Chichester. $458 \mathrm{p}$.

Karnwal A. 2017. Isolation and identification of plant growth promoting rhizobacteria from maize (Zea mays L.) rhizosphere and their plant growth promoting effect on rice (Oryza sativa L.). J. Plant Protect. Res. 57: 144-151.

Khalid A., Arshad M., Zahir Z.A. 2004. Screening plant growth promoting rhizobacteria for improving growth and yield of wheat. J. Appl. Microbiol. 96: 473-480.

Khan A.L., Halo B.A., Elyassi A., Ali S., Al-Hosni K., Hussain J., Al-Harrasi A., Lee I.J. 2016. Indole acetic acid and ACC deaminase from endophytic bacteria improves the growth of Solanum lycopersicum. Electr. J. Biotechnol. 21: 58-64.

Kim K., Jang Y.J., Lee S.M, Oh B.T., Chae J.C., Lee K.J. 2014. Alleviation of salt stress by Enterobacter sp. EJ01 in tomato and Arabidopsis is accompanied by up regulation of conserved salinity responsive factors in plants. Mol. Cell 37: 109-117.

Leelahawonge C., Pongsilp N. 2009. Factors influencing indole-3acetic acid biosynthesis of root nodule bacteria isolated from various leguminous plants. Thamasat Int. J. Sci. Tech. 14: 1-12.

Maheshwari D.K. 2012. Bacteria in Agrobiology: Stress Management. Springer, Berlin.

Marilley L., Aragno M. 1999. Phytogenetic diversity of bacterial communities differing in degree of proximity of Lolium perenne and Trifolium repens roots. Appl. Soil Ecol. 13: 127136.

Mukherjee B., Dutta S. 2019. Isolation of a phosphate solubilizing bacterial strain Bacillus tequilensis MCC 3872 from the rice field of Burdwan district and characterization of its plant growth promoting traits. Pharma Innov. J. 8: 956-962.

Nadeem S.M., Zahair Z.A., Naveed M., Asghar H.N., Asghar M. 2010. Rhizobacteria capable of producing ACC-deaminase may mitigate salt stress in wheat. Soil Sci. Soc. Am. 74: 533542.

Patten C.L., Glick B.R. 2002. Role of Pseudomonas putida indoleacetic acid in development of the host plant root system. Appl. Environ. Microbiol. 68: 3795-3801.

Prasad M., Srinivasan R., Chaudhary M., Choudhary M., Jat L.K. 2019. Plant growth promoting rhizobacteria (PGPR) for sustainable agriculture: perspectives and challenges. In: Singh A.K., Kumar A., Singh P.K. (Eds.) PGPR Amelioration in Sustainable Agriculture. Woodhead Publishing, pp. 129-157.

Ramalingam R., Abeer H., Elsayed F.A. 2017. Bacillus: a biological tool for crop improvement through bio-molecular changes in adverse environments. Front. Physiol. 8: 667.

Rodriguez H., Vidal R.F. 1999. Phosphate-solubilizing bacteria and their role in plant growth promotion. Biotechnol. Adv. 17: 319-339.

Rughöft S., Herrmann M., Lazar C.S., Cesarz S., Levick S.R., Trumbore S.E., Küsel K. 2016. Community composition and abundance of bacterial, archaeal and nitrifying populations in savanna soils on contrasting bedrock material in Kruger National Park, South Africa. Front. Microbiol. 7: 1638.

Sambrook J., Fritsch E.F., Maniatis T. 1989. Molecular Cloning: A Laboratory Manual. Cold Spring Harbor Laboratory Press, New York.

Santi M., Keshab C., Dey S., Pati B.R. 2007. Optimization of cultural and nutritional conditions for indole acetic acid 
production by a Rhizobium sp. isolated from root nodules of Vigna mungo (L.) Hepper. Res. J. Microbiol. 2: 239-246.

Sarkar A., Ghosh P.K., Pramanik K., Mitra S., Soren T., Pandey S., Mondal M.H. 2017. A halotolerant Enterobacter sp. displaying ACC deaminase activity promotes rice seedling growth under salt stress. Res. Microbiol. 169: 20-32.

Schwyn B., Neilands J.B. 1987. Universal chemical assay for the detection and determination of siderophores. Anal. Biochem. 160: 47-56.

Soto M.J., Sanjua'n J., Olivares J. 2006. Rhizobia and plantpathogenic bacteria: common infection weapons. Microbiology 152: 3167-3174.

Spaepen S., Vanderleyden J., Remans R. 2007. Indole-3-acetic acid in microbial and microorganism plant signaling. FEMS Microbiol. Rev. 31: 425-448.

Sridevi M., Mallaiah K.V. 2007. Bioproduction of indole acetic acid by Rhizobium strains isolated from root nodules of green manure crop, Sesbania sesban (L.) Merr. Iranian J. Biotechnol. 5: $178-182$.

Sridevi M., Yadav N.C.S., Mallaiah K.V. 2008. Production of indole acetic acid by Rhizobium isolates from Crolataria species. Res. J. Microbiol. 3: 276-281.
Tilak K.V.B.R., Ranganayaki N., Pal K.K., De R., Saxena A.K., Nautiyal C.S., Mittal S., Tripathi A.K., Johri B.N. 2005. Diversity of plant growth and soil health supporting bacteria. Curr. Sci. 89: 136-150.

Upadhyay S.K., Singh J.S., Singh D.P. 2011. Exopolysaccharide producing PGPR under salinity condition. Pedosphere 21: 214-222.

Vessey J.K. 2003. Plant growth promoting rhizobacteria as biofertilizers. Plant Soil 255: 571-586.

Wang M.S., Zapaa F.J., De Castro D.C. 1987. Plant regeneration through somatic embryogenesis from mature seed and young inflorescence of wild rice (Oryza perennis). Plant Cell Rep. 6: 294-296.

Yoon S.J., Choi Y.J., Min K., Cho K.K., Kim J.W., Lee S.C. 1996. Isolation and identification of phytase producing bacterium, Enterobacter sp. and enzymatic properties of phytase enzyme. Enzym. Microb. Technol. 18: 44- 454.

Yousef N. 2018. Capability of plant growth-promoting rhizobacteria (PGPR) for producing indole acetic acid (IAA) under extreme conditions. Eur. J. Biol. Res. 8: 174-182.

Zhao Y. 2010. Auxin biosynthesis and its role in plant development. Annu Rev. Plant Biol. 61: 49-64. 